\title{
HUBUNGAN STATUS GIZI DAN RIWAYAT PENYAKIT IBU DENGAN KEJADIAN BERAT BADAN LAHIR RENDAH DI RUMAH SAKIT MUHAMMADIYAH PALEMBANG TAHUN 2016
}

\author{
Wulan Citra Sari \\ Akademi Kebidanan Budi Mulia Prabumulih
} A B S T R A K

Informasi Artikel :

Diterima : April 2018

Disetujui : Mei 2018

Dipublikasikan : Juni 2018

*Korespondensi Penulis :
Data World Health Organizationmenurut WHO (2010) diperkirakan 15\% diseluruh kelahiran didunia dengan batasan 3,3\%-3,8\% dan lebih sering terjadi di negara berkembang atau ekonomi rendah.Tujuan Penelitian Diketahuinya hubungan status gizi dan riwayat penyakit ibu dengan kejadian BBLR di RumahSakit Muhammadiyah Palembang Tahun 2016. Populasi dalam penelitian ini adalah semua ibu bersalin 1881responden.Sampel pada penelitian ini adalah sebagian ibu bersalin 236 responden. Penelitian ini menggunakan desain penelitian kuantitatif dengan pendekatan Case Contro. di Rumah Sakit Muhammadiyah Palembang Tahun 2016. Analisa univariat Hasi penelitian ini yang BBLR pada kelompok kasus118 sedangkan yang tidak BBLR 118, dengan nilai OR 1:1 berdasarkan analisa bivariat didapat tidak ada hubungan yang bermakna antara status gizi dengan kejadian $(p$ value $=1,00)$ dan mengalami riwayat penyakit 117 dan tidak mengalami riwayat penyakit 119 menunjukan tidak ada hubungan yang bermakna antara riwayat penyakit dengan kejadian BBLR $(p$ value=0,60). Hasil penelitian ini diharapkan dapat menjadi bahan masukan bagi rumah saki tmuhmmadiyah untuk lebih meningkatkan mutu dan upaya pelayanan di rumah sakit.

\section{Kata Kunci : :Status,gizi,riwayatpenyakit,kejadianBBLR}

\section{ABSTRACT}

World Health Organization data according to WHO (2010) is estimated $15 \%$ in all births in the world with a limit of $3.3 \%-3.8 \%$ and is more common in developing countries or low economies. Research Objectives Knowing the relationship of nutritional status and history of maternal disease with $L B W$ occurrence in Hospital Muhammadiyah Palembang 2016. Population in this research is all maternal mother 1881responden.Sampel in this research is partially mother of 236 respondents. This research uses quantitative research design with Case Contro approach. at the hospital MuhammadiyahPalembang in 2016. Univariate analysis The result of this study is BBLR in the case group118, while those who are not BBLR 118, with OR 1: 1 score based on bivariate analysis, there is no significant relationship between nutritional status and occurrence ( $p$ value $=1,00$ ) and a history of disease 117 and no history of disease 119 showed no significant relationship between history of disease with the incidence of BBLR ( $p$ value $=0.60)$. The results of this study are expected to be input for Hospital muhammadiyah palembang to further improve the quality and service efforts in hospitals.

Keywords: Nutritional status, disease history, LBW occurrence 


\section{PENDAHULUAN}

Bayi Berat Badan Lahir Rendah ( BBLR) adalah bayi dengan berat badan lahirnya kurang dari 2500 gram tanpa memandang masa gestasi. Berat badan lahir rendah (BBLR) adalah berat badan bayi yang ditimbang dalam 1 jam setelah lahir (Puspitasari,2011).

World Health Organization WHO (2010) diperkirakan $15 \%$ diseluruh kelahiran didunia dengan batasan 3,3\%-3,8\% dan lebih sering terjadi di negara-negara berkembang atau ekonomi rendah. Secara statistik menunjukan $90 \%$ kejadian BBLR didapatkan di negara berkembang dan angka kematai sekitar 35 kali lebih tinngi dibanding pada bayi dengan berat badan lahir rendah (BBLR) lebih dari 2500 gram. Hal ini dapat terjadi dan dapat dipengaruhi oleh beberapa faktor seperti ibu mempunyai penyakit yang langsung berhubungan dengan kehamilan,dan usia ibu (Puspitasari,2011).

Menurut WHO BBLR adalah bayi yang lahir dengan berat badan lahir rendah kurang dari 2500 gram. Angka kematian bayi menjadi indikator utama dalam menentukan derajat kesehatan karena merupakan cerminan dari status kesehatan anak saat ini. Secara statistik, angka kesakitan dan angka kematian pada neonatus di negara berkembang adalah tertinggi, dengan penyebab utama adalah berkaitan dengan kejadian BBLR (Puspitasari, 2011).

Prevalensi BBLR menurut WHO (2010) diperkirakan 15\%diseluruh kelahiran didunia dengan batasan 3,3\%-3,8\% dan lebih sering terjadi di negara-negara berkembang atau ekonomi rendah. Secara statistik menunjukan $90 \%$ kejadian BBLR didapatkan di negara berkembang dan angka kematai sekitar 35 kali lebih tinggi dibanding pada bayi dengan berat badan lahir rendah (BBLR) lebih dari 2500 gram. Hal ini dapat terjadi dan dapat dipengaruhi oleh beberapa faktor seperti ibu mempunyai penyakit yang langsung berhubungan dengan kehamilan,dan usia ibu (Sartika Dewi, 2012).

Berat badan lahir rendah (BBLR), salah satunya disebabkan oleh status gizi dan riwayat penyakit ibu akan berakibat buruk terhadap janin. bukti-bukti menyebutkan bahwa kekurangan gizi pada ibu sebelum dan selama kehamilan dapat menyebabkan berat dadan lahir rendah (BBLR) (Sadle,2009; Louangpradith, 2010).

Untuk mengurangi kejadian Berat Badan Lahir Rendah (BBLR) salah satunya dengan cara memastikan bahwa ibu hamil mendapatkan gizi yang cukup. Status gizi ibu dapat diukur dengan menghitung Indeks Masa Tubuh (IMT) prahamil, yaitu BB : (TB/100²). (Alayne, 2003 ; Annie, 2009).

Angka kematian bayi untuk negara-negara dikota kawasan Association of South Esat Asian Nations (ASEAN) seperti Singapura sebanyak 3 per 1.000 kelahiran hidup, Brunei Darussalam 8 per 1.000 kelahiran hidup, malaysia sebanyak 10 per 1.000 kelahiran hidup, Viernam sebanyak 18 per 1.000 kelahiran hidup dan Thailand sebanyak 20 per 1.000 kelahiran hidup, sedangkan amgka kematian Indonesia masih menempati urutan tertinggi yaitu sebanyak 34 per 1.000 kelahiran hidup (Susanto, 2010)

Di negara- negara berkembang prevalensi berat badan lahir rendah (BBLR) diperkirakan 15\% dari keseluruh kelahiran didunia dengan batasan 3,3\%-38\%. Terjadi pada negara-negara yang sosial ekonominya rendah. Secara statistik menunjukkan 90\% kejadian BBLR terjadi di negara berkembang angka kematian lebih 35 kali lebih tinggi dibandingkan yang berat lahirnya diatas 2500 gram (Misna Tazkiah, 2013).

Indonesia saat ini masih menghadapi berbagai kendala dalam pembangunan sumber daya manusia khususnya dalam bidang kesehatan. Hal ini tampak dari tingginya angka kematian belita sebanyak $38 \%$ meninggal pada masa bayi baru lahir. Kematian bayi baru lahir di Indonesia terutama oleh prematuritas (32\%), asfiksia (30\%), infeksi (22\%), kelainan kongenital (7\%), lainlainnya (9\%) (JNPK-KR, 2008).

Dari data Riset Kesehatan Dasar (Riskesdas) tahun 2010 dalam Fikawati dkk, (2012) di seluruh Indonesia diperoleh angka kejadian BBLR sebesar 11,1\% dari seluruh angka kelahiran.Hasil ini sedikit lebih rendah dari hasil riskesdas tahun 2007 yang sebesar 11,5\%,tetapi masih jauh dari target BBLRyang ditetapkan pada sasaran program perbaikan gizi menuju Indonesia Sehat 2010 yakni 7\% (Fikawati, dkk, 2012).

Survei Demografi dan Kesehatan Indonesia (SDKI) tahun 2012, AKB di Indonesia adalah 32 per 1.000 kelahiran hidup sedangkan untuk Angka Kematian Neonatus (AKN) yaitu 19 per 1.000 kelahiran hidup. Dari seluruh kematian bayi di Indonesia sebanyak 46,2\% meninggal pada masa neonatus (usia dibawah 1 bulan). Penyebab kematian neonatus sebagian besar karena gangguan pernafasan/asfiksia $(35,9 \%)$ dan Bayi Berat Lahir Rendah (BBLR) $(32,4 \%)$ (Kemenkes, 2012).

Ada bebreapa faktor lain yang dapat mempengaruhi berat badan lahir rendah (BBLR), antara lain umur ibu, paritas, tinggi badan ibu,jarak kelahiran, perkerjaan ibu. Kehamilan yang tejadi 
pada usia dibawah 20 tahun atau diatas 35 tahun memiliki kencenderungan tidak terpenuhinya kebutuhan gizi yang angkut untuk pertumbuhan janin yang akan berdampak terhadap berat badan lahir bayi (Trihardiani, 2011)

Pencapaian dari indikator status gizi masyarakat tahun 2014 dilihat dari kasus berat badan lahir rendah (BBLR) yaitu kurang dari 2.500 gram yang merupakan salah satu faktor utama berpengaruh terhadap kematian perinatal dan neonatal. BBLR dibedakan menjadi 2 katagori yaitu : BBLR karena prematur (usia kandungan kurang dari 37 minggu) atau BBLR karena intrauterie growth retardation (IUDR), yaitu bayi lahir cukup bulan tetapi berat badannya kurang. Dinegara berkembang banyak BBLR dengan IUDR karena status gizi buruk, dan riwayat penyakit ibu seperti : hipertensi, malaria, preeklamsi berat, dan menderita penyakit menular seksual (PMS) sebelum konsepsi atau pada saat hamil (Dinas Kesehatan Sumatra Selatan,2014).

Bayi berat lahir rendah (BBLR) adalah bayi dengan berat lahir kurang dari 2500 gram tanpa memandang masa gestasi. Berat badan lahir rendah adalah yang ditimbang dalam 1 (satu) jam setelah lahir. Prevalensi berat badan lahir rendah (BBLR) diperkirakan $15 \%$ dari seluruh kelahiran di dunia dengan batasan 3,3\%-38\% dan lebih sering terjadi di negara berkembang atau sosial ekonomi rendah (Profil Kesehatan Kota Palembang,2014).

Berdasarkan data yang diperoleh dari Rumah Sakit Muhammadiyah Palembang, angka kejadian Berat Badan Lahir Rendah(BBLR) tahun 2013 sebesar 37,9 \% kasus BBLR dari 192 bayi yang dilahirkan dan tahun 2014 sebesar 36,9\% kasus BBLR dari 172 bayi yang dilahirkan dan pada tahun 2015 sebesar 34,5\% kasus BBLR dari 142 bayi, sedangkan pada tahun 2016 sebesar 50,0\% kasus BBLR dari 118 bayi yangdilahirkan RumahSakitMuhammadiyah Palembang, 2015).

Berdasarkan latar belakang diatas maka penulis tertarik untuk melakukan penelitian yang berjudul" Hubungan Status Gizi dan Riwayat penyakit Ibu dengan Kejadian Berat Badan Lahir Rendah di Rumah Sakit Muhammadiyah Palembang tahun 2016

\section{METODE PENELITIAN}

Metode penelitian ini yang akan digunakan adalah kuantitatif dengan pendektan case control dimana penelitian mengukur atau mengumpulkan Variabel Indefenden (Status Gizi dan Riwayat Penyakit Ibu) dan Variabel Dependen Berat Badan Lahir Rendah (BBLR) yang akan dikumpulkan dalam waktu tempat yang bersamaan.
Penelitian ini untuk mempelajari hubungan antara paparan variabel independen (Status Gizi dan Riwayat Penyakit ibu) dengan variabel dependen (kejadian Berat Badan Lahir Rendah) dan membandingkan dengan kelompok kontrol (ibu bersalin spontan) dengan melihat ke belakang dari suatu kejadian yang berhubungan (retrosfektif).

\section{Bagan 1 Desain penelitian Case Control}

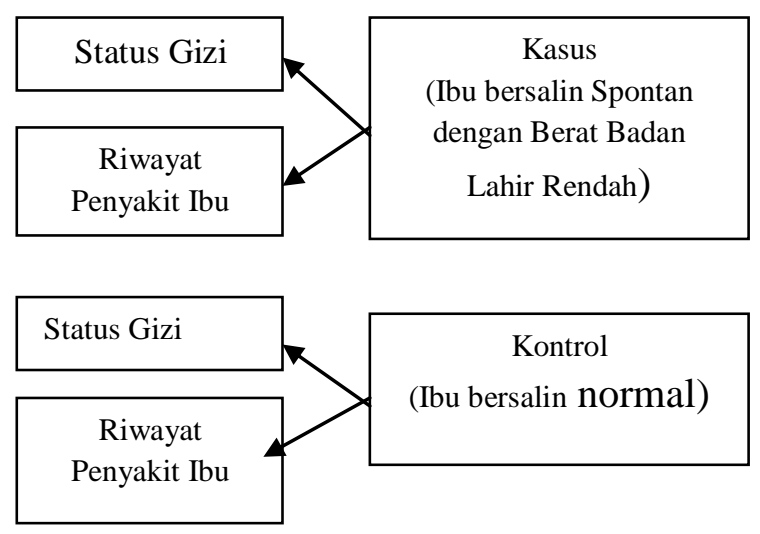

Populasi dalam penelitian ini adalah seluruh ibu bersalin di Rumah Sakit Muhammadiyah Palembang Tahun 2016 sebanyak 1881 responden, 118 ibu yang bersalin dan 118 ibu yang bersalin dengan kejadian BBLR

Sampel pada penelitian ini adalah ibu bersalin dengan Berat Badan Lahir Rendah sebanyak 118 responden sebagai kelompok kasus dan ibu bersalin sebanyak 118 responden sebagai kelompok kontrol dengan perbandingan kasus:kontrol adalah Odd Ratio (OR) 1:1.

Pengambilan sampel pada secara Lotre disiapkan 1881 responden kemudian diLotre setiap kali nomor urut hasi pengundian dicatat sebagai sampel yang diundi sampai 236 sampel, Jadi Jumlah sampel pada penelitian ini sebanyak 236 responden

Analisa univarat bertujuan untuk menggambarkan secara sistematis fakta atau karakteristik populasi tertentu atau bidang tertentu secara aktual dan cermat. Analisa yang dimaksud untuk mendeskripsikan masing-masing variabel independen Analisis yang dilakukan dengan melihat distribusi frekuensi dari masing-masing kategori variabel dependen (Kejadian Berat Badan Lahir rendah) dan variabel independen (Status Gizi dan Riwayat Penyakit Ibu).

Analisis bivariat yang bertujuan untuk melihat hubungan antara variabel dependen (kejadian Berat Badan Lahir Rendah) dan variabel independen (Status Gizi dan Riwayat Penyakit Ibu) dengan uji kuadrat (Chi Square).

Analisa ini bertujuan untuk melihat hubungan antara 2 variabel dengan menggunakan 
uji chi square, bentuk uji hubungan digunakan tingkat kepercayaan $95 \%$ pada $\alpha$ 0,05.Analisa bivariat dilakukan terhadap dua variabel yang diduga berhubungan. Untuk membuktikan apakah hipotesa diterima / ditolak, dengan menggunakan $\mathrm{x}^{2}$ (chi square) .

\section{HASIL PENELITIAN}

\section{Analisis Univariat}

Analisis univariat yaitu analisis yang dilakukan terhadap satu variabel. Analisis ini dilakukan pada setiap variabel yang diteliti.

\section{Tabel 1 Distribusi Frekuensi}

Berdasarkankejadian Berat Badan

Lahir Rendah (BBLR) di Rumah Sakit Muhammadiyah Palembang Tahun 2016

\begin{tabular}{llcc}
\hline No & BBLR & Frekuensi & \% \\
\hline 1. & Ya & 118 & 50 \\
\hline 2. & Tidak & 118 & 50 \\
\hline & Total & $\mathbf{2 3 6}$ & $\mathbf{1 0 0 \%}$ \\
\hline
\end{tabular}

Berdasarkan tabel 2 di atas dari 236 responden didapatkan yang menunjukkan kelompok kasus ibu yang bersalin bayi dengan BBLR adalah 118 responden (50,0\%), sedangkan kelompok kontrol ibu yangbersalin bayi dengan tidak BBLR sebanyak 118 orang $(50,0 \%)$.

Tabel 2 Distribusi Frekuensi Berdasarkan Status Gizi di Rumah Sakit Muhammadiyah Palembang Tahun 2016

\begin{tabular}{cccc}
\hline No. & Status Gizi & Frekuensi & $\mathbf{( \% )}$ \\
\hline 1. & Gizi baik & 103 & 43,6 \\
\hline 2. & Gizi kurang & 133 & 56,4 \\
\hline & Total & $\mathbf{2 3 6}$ & $\mathbf{1 0 0 \%}$ \\
\hline
\end{tabular}

Berdasarkan tabel 3 diatas dari 236 respoden didapatkan yang menunjukan ibu yang memiliki gizi baik yaitu sebanyak 103 orang ( 43,6\%) sedangkan Gizi kurang adalah sebanyak 133 orang $(56,4 \%)$.

Tabel 3 Distribusi Frekuensi Berdasarkan Riwayat penyakit ibu di Rumah Sakit Muhammadiyah Palembang Tahun 2016

\begin{tabular}{cccc}
\hline No. & $\begin{array}{c}\text { Riwayat } \\
\text { Penyakit } \\
\text { Ibu }\end{array}$ & Frekuensi & $\mathbf{( \% )}$ \\
\hline 1 & Iya & 117 & 49,6 \\
\hline 2 & Tidak & 119 & $50,4 \%$ \\
\hline & Total & $\mathbf{2 3 6}$ & $\mathbf{1 0 0} \%$ \\
\hline
\end{tabular}

Berdasarkan dari tabel 4 Dari 236

Responden didapatkan yang menunjukan ibu yang mengalami riwayat penyakit adalah 117 orang $(49,6 \%)$, sedangkan yang tidak mengalami riwayat penyakit adalah sebanyak 119 orang $(50,4 \%)$.

\section{A. Analisis Bivariat}

Analisis bivariat adalah analisis yang dilakukan terhadap dua variabel yang diduga berhubungan. Dalam penelitian ini analisis bivariat digunakan untuk mengetahui hubungan melihat hubungan Status Gizi dengan terjadinya berat badan lahir rendah (BBLR) di Rumah Sakit Muhammadiyah Palembang tahun 2016, Untuk mengetahui hubungan ini digunakan uji Chi Square dimana hasilnya disajikan pada tabel berikut ini.

Tabel 4 Hubungan Status Gizi dengan Terjadinya BBLR di Rumah Sakit Muhammadiyah PalembangTahun 2016

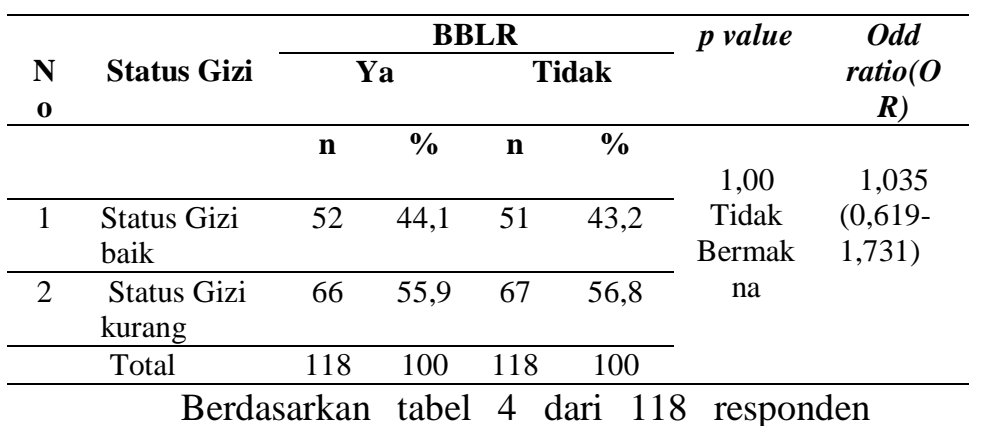
kelompok kasus yang mengalami BBLR dengan status gizi baik sebanyak 52 responden ( $44,1 \%$ ), dan yang mengalami BBLR dengan status gizi kurang 66 responden $(55,9 \%)$ sedangkan 118 responden kelompok kontrol yang tidak mengalami BBLR dengan Status Gizi baik sebanyak 51 responden $(43,2 \%)$, yang tidak mengalami BBLR dengan status gizi kurang 67 responden $(56,8 \%)$.

Uji Chi-Square menunjukan $p$ value $=(1,00)$ lebih besar dari $\alpha(0,05)$, yang berarti tidak ada hubungan yang bermakna antara Status Gizi dengan kejadian BBLR, odd ratio (OR) 1,035 status gizi yang beresiko tejadinya Berat Badan Lahir Rendah (BBLR) dengan status gizi baik atau status gizi kurang OR 1,035 yang beresiko dengan kejadian Berat Badan Lahir Rendah (BBLR).

Penelitian ini menunjukan data antara status gizi baik dan status gizi buruk pempunyai nilai seimbang, dan lebih mempunyai kecendrungan tidak bermakna selain itu dapat disebabkan karena status gizi adalah salah satu penyebab predispososi dari kejadian Berat Badan Lahir Rendah (BBLR). Sehingga hipotesis yang menyatakan tidak ada hubungan antara antara Status gizi dengan kejadian 
BBLR di Rumah Sakit Muhammadiyah Palembang tahun 2016, terbukti secara statistik.

Tabel 5 Hubungan Riwayat penyakit Ibu dengan Terjadinya BBLR di Rumah sakit muhamadiyah Palembang 2017.

\begin{tabular}{|c|c|c|c|c|c|c|c|}
\hline \multirow{3}{*}{$\begin{array}{l}\mathbf{N} \\
\mathbf{o}\end{array}$} & \multirow{3}{*}{$\begin{array}{c}\text { Riwayat } \\
\text { penyakit } \\
\text { ibu }\end{array}$} & \multicolumn{4}{|c|}{ BBLR } & \multirow{3}{*}{$\begin{array}{c}p \\
\text { value }\end{array}$} & \multirow{3}{*}{$\begin{array}{l}\text { Odd } \\
\text { ratio }\end{array}$} \\
\hline & & \multicolumn{2}{|c|}{ Ya } & \multicolumn{2}{|c|}{ Tidak } & & \\
\hline & & n & $\%$ & n & $\%$ & & \\
\hline 1 & Iya & 56 & 47,5 & 61 & 51,7 & \multirow{3}{*}{$\begin{array}{l}0,60 \\
\text { Tidak } \\
\text { berma } \\
\text { kna }\end{array}$} & \multirow{3}{*}{$\begin{array}{r}0,844 \\
(0.506- \\
1,407)\end{array}$} \\
\hline 2 & Tidak & 62 & 52,5 & 57 & 48,3 & & \\
\hline & Total & 118 & 100 & 118 & 100 & & \\
\hline
\end{tabular}

Berdasarkan tabel 5 Dari 118 responden

kelompok kasus yang mengalami BBLR dengan riwayat penyakit pada ibu sebanyak 56 responden ( 47,5\%), dan yang mengalami BBLR dengan dan tidak mengalami riwayat penyakit sebanyak 62 responden $(52,5 \%)$, sedangkan 118 responden kelompok kontrol yang tidak mengalami BBLR dengan riwayat penyakit ibu sebanyak 61 responden $(51,7 \%)$, serta yang tidak mengalami BBLR dengan tidak mengalami riwayat penyakit ibu 57 responden $(48,3 \%)$.

Uji Chi-Square menunjukan $p$ value $=(0,60)$ lebih besar dari $\alpha(0,05)$, yang berarti tidak ada hubungan Riwayat penyakit ibu dengan terjadinya BBLR.

Odd ratio 0,844 riwayat penyakit ibu yang beresiko terjadinya BBLR dengan ibu yang mengalami riwayat penyakit atau ibu yang tidak mengalami riwayat penyakit OR 0,844 beresiko dengan kejadian BBLR.

Penelitian ini menunjukan bahwa data antara ibu yang mengalami riwayat penyakit dan ibu yang tidak mempunyai riwayat prnyakit mempunyai nilai seimbang dan lebih cendrung tidak bermakna selain itu dapat disebabkan riwayat penyakit ibu adalah salah satu penyebab predisposisi kejadian Berat Badan Lahir Rendah (BBLR).

Sehingga hipotesis yang menyatakan tidak ada hubungan riwayat penyakit ibu dengan kejadian BBLR di Rumah Sakit Muhammadiyah Palembang tahun 2016, terbukti secara statistik.

\section{PEMBAHASAN}

Penelitian ini menggunakan metode kuantitatif dengan menggunakan pendekatan case control dimana data variabel dependen (BBLR) dan variabel independen (Status Gizi dan Riwayat penyakit ibu ) diambil dalam waktu yang bersamaan.Pembahasan hasil penelitian ini berdasarkan data rekam medik sehingga memberikan kontribusi kearah perbaikan yang positif. Dalam penelitian ini masih banyak keterbatasan waktu, jumlah sampel dan desain penelitian.

Pada penelitian yang dilakukan di Rumah Sakit Muhammadiyah Palembang menunjukan ibu yang bersalin bayi dengan berat badan lahir rendah (BBLR) memiliki persentasi yang masih tinggi yaitu kelompok kasus sebanyak 118 reponden $(50,0 \%)$ sedangkan ibu yang bersalin bayi tidak dengan berat badan lahir rendah (BBLR) kelompok kontrol sebanyak 118 responden $(50,0 \%)$.

Berdasarkan Hasil Penelitian ini menunjukan 118 responden dengan kejadian BBLR diKarena rumah sakit muhammadiyah adalah salah satu rumah sakit rujukkan sehingga menyebabkan tingginya angka kejedian berat badan lahir rendah (BBLR) Sehingga hal ini menunjukan bahwa ibu tidak memperhatikan kehamilanya, karena faktor status Gizi, Riwayat penyakit dan tidak melakukan pemeriksaan Antenal Care (ANC).

\section{Status Gizi}

Hasil penelitian ini menunujukakn ibu besraslin dengan Status gizi baik 103 responden $(44,6 \%)$ dan sedangkan ibu bersalin degan status gizi kurang 133 responden $(56,4 \%)$

Analisa bivariat menunjukan dari dari 118 responden kelompok kasus yang mengalami BBLR dengan gizi baik sebanyak 52 responden $(44,1 \%)$,dan yang mengalami BBLR dengan status gizi kurang 66 responden $(55,9 \%)$ sedangkan 118 responden kelompok kontrol yang tidak mengalami BBLR dengan Status Gizi baik sebanyak 51 responden $(43,2 \%)$, yang tidak mengalami BBLR dengan status gizi kurang 67 responden $(56,8 \%)$.

Uji Chi-Square menunjukan $p$ value $=$ $(1,00)$ lebih besar dari $\alpha(0,05)$, yang berarti tidak ada hubungan yang bermakna antara Status Gizi dengan kejadian BBLR. , odd ratio (OR) 1,035 status gizi yang beresiko tejadinya Berat Badan Lahir Rendah (BBLR) dengan status gizi baik atau status gizi kurang OR 1,035 yang beresiko dengan kejadian Berat Badan Lahir Rendah (BBLR).

Penelitian ini menunjukan data antara status gizi baik dan status gizi buruk pempunyai nilai seimbang, dan lebih mempunyai kecendrungan tidak bermakna selain itu dapat disebabkan karena status gizi adalah salah satu penyebab predispososi dari kejadian Berat Badan Lahir Rendah (BBLR).

Sehingga hipotesis yang menyatakan tidak ada hubungan antara antara Status gizi dengan kejadian BBLR di Rumah Sakit 
Muhammadiyah Palembang tahun 2016, terbukti secara statistik.

Untuk mengurangi kejadian Berat Badan Lahir Rendah (BBLR) salah satunya dengan cara memastikan bahwa ibu hamil mendapatkan gizi yang cukup. Status gizi ibu dapat diukur dengan menghitung Indeks Masa Tubuh (IMT) prahamil, yaitu BB : $\left(\mathrm{TB} / 100^{2}\right)$. (Alayne, 2003 ; Annie, 2009).

Berdasarkan teori Syafig et al, (2010), kurang energi kronis (KEK) yang dinilai dengan LILA berpengaruh terhadap kejadian berat badan lahir rendah (BBLR). KEK berdampak negatif terhadap ibu hamil dan janin yang dikandungnya berupa peingkatan kematian ibu saat melahirkan bayi dengan berat badan lahir rendah (BBLR).

Ibu yang mengalami kurang asupan gizi akan berdampak buruk bagi kesehatannya, ditambah lagi diperlukan tenaga yang banyak saat melahirkan. Status gizi ibu yang kurang pada saat hamil, akan membawa dampak terhadap janin yang dikandung. Pertumbuhan janin didalam kandungan tidak optimal, bahkan sampai lahir akan berdampak pada pertumbuhan dan perkembangan sesudah lahir.

Menurut Khairina dan Robiana Modjo (2013), Status gizi adalah hasil analisis dari hubungan antara status gizi ibu dengan kejadian Berat Badan Lahir Rendah (BBLR) diketahui bahwa 3 responden (43\%) ibu dengan status gizi kurang melahirkan bayi berat badan lahir rendah (BBLR). Sedangkan 6 responden $(7 \%)$ melahirkan bayi berat badan lahir rendah (BBLR). Hasil uji statistik diperoleh nilai $p$ value 0,005, maka dapat disimpulkan ada hubungan yang signifikan antara stastus gizi ibu dengan kejadian berat badan lahir rendah (BBLR). Dari hasil analisis diperoleh nilai OR 1,1 artinya ibu dengan status gizi kurang mempunyai peluang 11 kali untuk melahirkan bayi dengan berat badan lahir rendah(BBLR).

Berdasarkan hasil penelitian ini menunujukkan bahwa 103 responden yang mengalami gizi baik dengan kejadian BBLR sedangkan yang mengalami gizi kurang sebanyak 133 responden dengan kejadian BBLR dirumah sakit muhammadiyah, dikarenakan ibu banyaknya menggunakan kartu BPJS, KIS bisa dikatakan dari ekonomi rendah sehingga kurang memperhatikan Status gizi Ibu yang mengalami kurangnya asupan gizi akan berdampak buruk bagi kesehatannya dapat menyebabkan kejadian BBLR, Status gizi ibu yang kurang pada saat hamil, akan membawa dampak terhadap janin yang dikandung.
Pertumbuhan janin didalam kandungan tidak optimal, bahkan sampai lahir akan berdampak pada pertumbuhan dan perkembangan sesudah lahir.

Berdasrkan hasil penelitian saya dapat disimpulkan bahwa tidak ada hubungan bermakna antara status gizi dengan kejadian berat badan lahir rendah (BBLR) dan Status Gizi lebih cendrung tidak memberikan pengaruh kontrabusi terhadap terjadinya berat badan lahir rendah

\section{Riwayat penyakit Ibu}

Analisa univariat pada paritas ibu bersalin spontan dengan riwayat penyakit ibu 117 responden $(49,6 \%)$ dan sedangkan ibu bersalin spontan dengan riwayat penyakit 119 responden $(50,0 \%)$

Analisa bivariat menunjukan Dari 118 responden kelompok kasus yang mengalami BBLR dengan riwayat penyakit pada ibu sebanyak 56 responden ( $47,5 \%)$, dan yang mengalami BBLR dengan dan tidak mengalami riwayat penyakit sebanyak 62 responden $(52,5 \%)$, sedangkan 118 responden kelompok kontrol yang tidak mengalami BBLR dengan riwayat penyakit ibu sebanyak 61 responden $(51,7 \%)$, serta yang tidak mengalami BBLR dengan tidak mengalami riwayat penyakit ibu 57 responden $(48,3 \%)$.

Uji Chi-Square menunjukan $p$ value $=$ $(0,60)$ lebih besar dari $\alpha(0,05)$, yang berarti tidak ada hubungan Riwayat penyakit ibu dengan terjadinya BBLR. odd ratio 0,844 riwayat penyakit ibu yang beresiko terjadinya BBLR dengan ibu yang mengalami riwayat penyakit atau ibu yang tidak mengalami riwayat penyakit OR 0,844 beresiko dengan kejadian BBLR.

Penelitian ini menunjukan bahwa data antara ibu yang mengalami riwayat penyakit dan ibu yang tidak mempunyai riwayat prnyakit mempunyai nilai seimbang dan lebih cendrung tidak bermakna selain itu dapat disebabkan riwayat penyakit ibu adalah salah satu penyebab predisposisi kejadian Berat Badan Lahir Rendah (BBLR).

Sehingga hipotesis yang menyatakan tidak ada hubungan riwayat penyakit ibu dengan kejadian BBLR di Rumah Sakit Muhammadiyah Palembang tahun 2016, terbukti secara statistik.

Berdasarkan teori Lalage,(2013) tekanan darah tinggi (hipertensi) dapat mengakibatkan menurun aliran darah ke plasenta, yang akan mempengaruhi persediaan oksigen dan nutrisi 
pada bayi. Hal ini dapat memperlamat pertumbuhan janin dan meningkatkan resiko saat melahirkan. Ibu hamil dengan hipertensi pempunyai resiko tinggi untuk komplikasi berat seperti penyakit jantung, penyakit pembuluh darah otak, atau gagal organ hingga kematian. Sedangkan terhadap janin, hipertensi mengakibatkan perkembangan janin dalam rahim terlamat, kelahiran sebelum waktunya dan kematian janin dalam rahim.

Bayi yang dilahirkan dari ibu yang hipertensi dapat mengalami berbagai masalah kesehatan dan bayi mempunyai berat badan lahir rendah. Hal ini disebabkan karena terganggunya aliran darah didalam tubuh ibu.

Menurut Khairina dan Robiana Modjo (2013), adalah hasil dari analisis hubungan antara riwayat hipertensi ibu dengan kejadian berat badan lahr rendah (BBLR) diketahui bahwa 3 responden (30\%) ibu yang hipertensi melahirkan bayi berat badan lahir rendah (BBLR). Sedangkan ibu yang tidak mempunyai riwayat hipertensi 6 responden (7\%) melahirkan berat badan lahir rendah (BBLR). Hasil uji statistik diperoleh p-value 0,004, maka dapat simpulkan bahwa ada hubungan signifikan antara riwayat hipertensi ibu dengan kejadian berat badan lahir rendah (BBLR). Dari hasil analisis diperoleh nilai OR 6, artinya ibu dengan riwayat hipertensi mempunyai peluang 6 untuk melahirkan bayi berat badan lahir rendah (BBLR).

Berdasarkan penelitian ini menunjukan 117 responden yang mengalami riwayat penyakit dengan kejadian BBLR sedangkan 119 responden yang tidak mengalami riwayat penyakit lebih tinggi dengan kejadian BBLR. Dan ibu-ibu hamil yang mengalami riwayat penyakit seperti mengalami komplikasi kehamilan, anemia, pendarahan antepartum, hipertensi, preeklamsia, infeksi kandung kemih, malaria, infeksi menular seksual, HIV/AIDS, TORCH, penyakit jantung, dan Penyalahgunaan obat, merokok, konsumsi alkohol dapat menyebabkan kejadian BBLR.

Berdasarkan hasil penelitian saya dapat disimpulkan bahwa tidak ada hubungan antara riwayat penyakit dengan kejadian Berat Badan Lahir rendah (BBLR) dan Riwayat penyakit ibu cendrung tidak memberikan pengaruh kontrabusi terhadap terjadinya berat badan lahir rendah.

\section{KESIMPULAN}

Berdasarkan uraian dan pembahasan hasil penelitian yang telah dilakukan ada 118 kelompok kontrol ibu bersalin dan 118 kelompok kasus ibu bersalin dengan kejadian Berat Badan Lahir Rendah (BBLR) di Rumah Sakit Muhammadiyah Palembang Tahun 2016.

1. Distribusi frekuensi kejadian Berat Badan Lahir Rendah (BBLR). kelompok kasus ibu yang bersalin bayi dengan BBLR adalah 118 responden $(50,0 \%)$, sedangkan kelompok kontrol ibu yang bersalin bayi dengan tidak BBLR sebanyak 118 orang $(50,0 \%)$.

2. Distribusi frekuensi Status gizi dengan kejadain Berat Badan Lahir Rendah (BBLR). yang menunjukan ibu yang memiliki gizi baik yaitu sebanyak 103 orang ( 43,6\%) sedangkan Gizi kurang adalah sebanyak 133 orang $(56,4 \%)$.

3. Distribusi Frekuensi Riwayat penyakit Ibu dengan kejadian Berat Badan Lahir Rendah (BBLR) yang menunjukan ibu yang mengalami riwayat penyakit adalah 117 orang $(49,6 \%)$, sedangkan yang tidak mengalami riwayat penyakit adalah sebanyak 119 orang $(50,4 \%)$.

4. hubungan antara Status gizi dengan kejadian Berat Badan Lahir Rendah (BBLR), $p$ value $=$ $(1,00)$ lebih besar dari $\alpha(0,05)$, yang berarti tidak ada hubungan yang bermakna antara Status Gizi dengan kejadian BBLR. Sehingga hipotesis yang menyatakan tidak ada hubungan antara antara Status gizi dengan kejadian BBLR, terbukti secara statistik.

5. hubungan antara Riwayat penyakit ibu Berat Badan Lahir Rendah (BBLR). $p$ value $=(0,60)$ lebih besar dari $\alpha(0,05)$, yang berarti tidak ada hubungan Riwayat penyakit ibu dengan terjadinya BBLR. Sehingga hipotesis yang menyatakan tidak ada hubungan riwayat penyakit ibu dengan kejadian BBLR, terbukti secara statistik.

\section{DAFTAR PUSTAKA}

Alya, 2013 faktor-faktor yangberhubungan dengan bayi berat badan lahir rendah. Dirumah sakit ibu dan anak.

Dinkes Kota Palembang, 2014. Profil Kesehatan Kota Palembang Tahun 2014.

Dinas Kesehatan Provinsi Sumsel Palembang, 2014. Profil Kesehatan Kota Palembang Tahun 2014.

Fikawati dkk, 2012. Status Gizi Ibu Hamil dan Berat Lahir Bayi pada kelompok Vegetarian. Makara, Kesehatan, Vol, No.1,Juni 2012

Kemenkes RI, 2012. Survei Demografi dan Kesehatan Indonesia 2012. Diakses tanggal $10 \quad$ Mei $2017 \quad$ melalui http://www.bkkbn.go.id/litbang/pusdu/Hasil 
\%20Penelitian/SDKI\%202012/Laporan\%20

Pendahuluan\%20SDKI

Kemenkes RI. 2014. Upaya penataleksanaan esensial Bayi Baru Lahir dengan BBLR di Indonesia

Khariana, robinana modjo, 2013. Kebidanan komunitas. depertemen k3 fakultas kesehatan masyarakat universitas indonesia.

Lalage, zerina, 2013. Menghadapi kehamilan berisko tinggi. Jakarta : abata press klaten.

Louangrradith, 2010. Analisis faktor resiko yang berhubungan dengan kejadian berat badan lahir rendah (BBLR) dalam konteks maternkitas dirumah sakit palang marah indonesia kota bogor 2010 http:lontar .ui.ac.id.

Misna Tazkiah, 2013. Epidemiological Determinants Low Birth Weight in Malaria Areas Banjar District. Banjar Provinsi kalimantan selatan.

Mutianngsih Rosa, 2012. Hubungan anata bayi berat badan lahir rendah dengan kejadian ikterus, hipoglikemi dan infeksi neonatorum. universitas brawijaya malang.

Notoatmodjo, 2010. Metodologi penelitian kesehatan. Jakarta: Rineka cipta.

Nugroho,2010. Masalah BBLR diindonesia, Jakarta: Salema Medika.

Pantiawati, 2010. Bayi dengan BBLR Yogyakarta: Nuha Medika

Puspitasari, 2011. Ibu hamil sebagai resiko BBLR. Aceh Gadja Mada.

Proverawati dan ismawati, 2010. Berat badan lahir rendah. Yogyararta: nuha medika djo, 2010. llmu kebidanan. Jakarta: penerbit bina pustaka

Profil Rumah Sakit Muhammadiyah Palembang Tahun 2015.

Sartika Dewi, 2012. BBLR Dengan Dismatur. http://dewisartika172.blogspot.com/2012/12/ kti-bblr-dengan-dismatur.html

Saifudin,2009. Asuhan keperawatan maternal, jakarta : Salema medika. 
